\title{
First findings of centrohelid heliozoans (Haptista: Centroplasthelida) from marine and freshwater environments of South Korea
}

\author{
Dmitry G. Zagumyonnyi ${ }^{1}$, Kristina I. Prokina ${ }^{1}$ and \\ Denis V. Tikhonenkov ${ }^{1,2}$
}

\author{
${ }^{1}$ Papanin Institute for Biology of Inland Waters Russian Academy of Sciences, \\ 152742 Borok, Russia \\ ${ }^{2}$ AquaBioSafe laboratory, University of Tyumen, Tyumen 625003, Russia
}

| Submitted October 24, 2020 | Accepted December 6, 2020 |

\begin{abstract}
Summary
The morphology of the siliceous scales and organic spicules of centrohelid heliozoans collected from two river sites and one marine site in South Korea has been investigated. Five species including one subspecies, one centrohelidian identified at the genus level, and Heterophrys-like organisms were examined. New species, Pterocystis jongsooparkii sp. nov. was described. This heliozoan is characterized by the unique morphology of spine scales: lateral wings ornamented by 10-15 transverse slits; the sides of lateral wings are bent into a marginal rim, and distal sides of lateral wings are sharply cut, forming "shoulders"; the distal part of the shaft has several rounded teeth. The SSU rRNA gene phylogeny placed $P$. jongsooparkii within Pterista as a separate phylogenetic lineage in an unresolved trichotomy with Pterocystidae $\mathrm{C}$ and the clade, uniting representatives of Pterocystidae B, Heterophryidae, and environmental sequence Env H10.4. Heliozoan Raphidocystis sp. is distinguished from other Raphidocystis species by the presence of only one type of scales - almost circular plate scales with a slight medial thickening, and was not assigned to any known species. All the species found in this survey are new for South Korea. The present study complements the available information on the centrohelid phylogeny and biogeography. The morphological data obtained from observed species expand our knowledge on the intraspecific variability of centrohelid heliozoans.
\end{abstract}

Key words: protists, morphology, electron microscopy, skeletal elements, Pterocystis jongsooparkii, 18S rRNA, molecular phylogeny

Abbreviations: DIC - differential interference contrast, $\mathrm{PhC}$ - phase contrast, SEM - scanning electron microscopy, TEM - transmission electron microscopy

doi:10.21685/1680-0826-2020-14-4-4 


\section{Introduction}

Heliozoans are a polyphyletic group of non-flagellate predatory protists with spherical cell body and radially diverging axopodia with extrusomes. Axopodia are used for capturing prey and floating in the water or moving along a substrate. Centrohelid heliozoans, also known as centrohelids (Centroplasthelida Febvre-Chevalier et Febvre, 1984 ) is the largest holophyletic taxon of heliozoans. The position of centrohelids on the eukaryotic tree remained unknown until recently. Multigene phylogeny has shown that centrohelids are sister to haptophytes. Together with them, centrohelids form a clade called Haptista (Burki et al., 2016). Centrohelid heliozoans play an important role in the aquatic food webs since they feed on small protists and bacteria, as shown for Oxnerella micra (CavalierSmith and Chao, 2012) and thereby are able to control their abundance (Siemensma, 1991; Arndt, 1993; Stensdotter-Blomberg, 1998; Mikrjukov, 2002). Despite this important role, centrohelids remain one the least studied components in aquatic ecosystems, especially in marine waters (Siemensma, 1991; Mikrjukov, 2002).

Centrohelid heliozoans are characterized by a unique morphology of the microtubule-organizing center (MTOC) and variable cell coverings (Nicholls, 1983; Siemensma, 1991; Mikrjukov, 2002). These coverings have a taxonomic significance and can be divided into several types: siliceous scales (in Acanthocystis, Choanocystis, Parasphaerastrum, Pinjata, Pseudoraphidiophrys, Pseudoraphidocystis, Pterocystis, Raineriophrys, Raphidiophrys, Raphidocystis, and Yogosothoth); organic spicules (in Heterophrys, Marophrys, Sphaerastrum, and Spiculophrys); a combination of siliceous scales and organic spicules (in Raphidiophrys, Raphidocystis); and mucous coat (in Chlamydaster). In one genus (Oxnerella) the coverings are absent (Siemensma, 1991; Mikrjukov, 2002; Cavalier-Smith and von der Heyden, 2007; Cavalier-Smith and Chao, 2012; Zlatogursky, 2012, 2016; Zlatogursky et al., 2018, 2019; Shishkin et al., 2018; Drachko et al., 2020).

The study of centrohelids began in the second half of the 19th century using light microscopy (Carter, 1863, 1865; Archer, 1867, 1869; Greef, 1869, 1873; Penard, 1889, 1890). When electron microscopy came into use, it was found that the morphology of siliceous scales of centrohelids is extremely diverse possessing diagnostic species-specific value. Within a short period of time, a large number of new species were discovered, diagnoses of known species were amended, and a significant taxonomic revisions were carried out (Nicholls, 1983; Dürrschmidt, 1985, 1987a, 1987b; Croome, 1986, 1987; Siemensma and Roijackers, 1988a, 1988b; Mikrjukov, 1996a, 1996b, 1997). Nevertheless, centrohelid heliozoans remain one of the least studied groups of protists at both the morphological and molecular level. The study of these organisms is hindered by the difficulty of culturing, as well as the necessity of using electron microscopy for species identification. Many taxonomic issues remain unresolved due to the almost complete absence of molecular data. Only about 100 morphospecies of centrohelid heliozoans are known today. Cavalier-Smith and von der Heyden (2007) suggested that only 10\% of centrohelid diversity has been morphologically characterized for now. This assumption is confirmed by the regular findings of the new species of centrohelids (Cavalier-Smith and von der Heyden, 2007; Leonov, 2010; Tikhonenkov and Mylnikov, 2011; Zlatogursky, 2010, 2014; Zlatogursky et al., 2017, 2019; Prokina et al., 2019).

At the same time, little is known about the geographical distribution of centrohelid heliozoans. Are they widespread all over the world, or do they, like macroorganisms, obey the general rules of historical biogeography? The same morphospecies of heliozoans have been found in different regions around the globe (Nicholls, 1983; Dürrschmidt, 1985, 1987a, 1987b; Croome, 1986, 1987; Siemensma and Roijackers, 1988a, 1988b; Prokina et al., 2019). Therefore, we can assume the cosmopolitan nature of their distribution. However, these results can be strongly affected by misidentification, insufficient sampling, and scarcity or complete lack of data for some regions. For example, there are no data on centrohelid heliozoans from South Korea.

Here we present the first information on species composition, as well as morphological and molecular data on centrohelid heliozoans from the fresh and marine waters of South Korea with the descriptions of a new species.

\section{Material and methods}

\section{Cultures And SAmples}

Samples were taken from two river sites (coastal benthos and periphyton on stones) and two marine sites (coastal benthos and interstitial water within the sand and mollusk shells on the littoral) in the southeast part of the Republic of Korea (Fig. 1; 


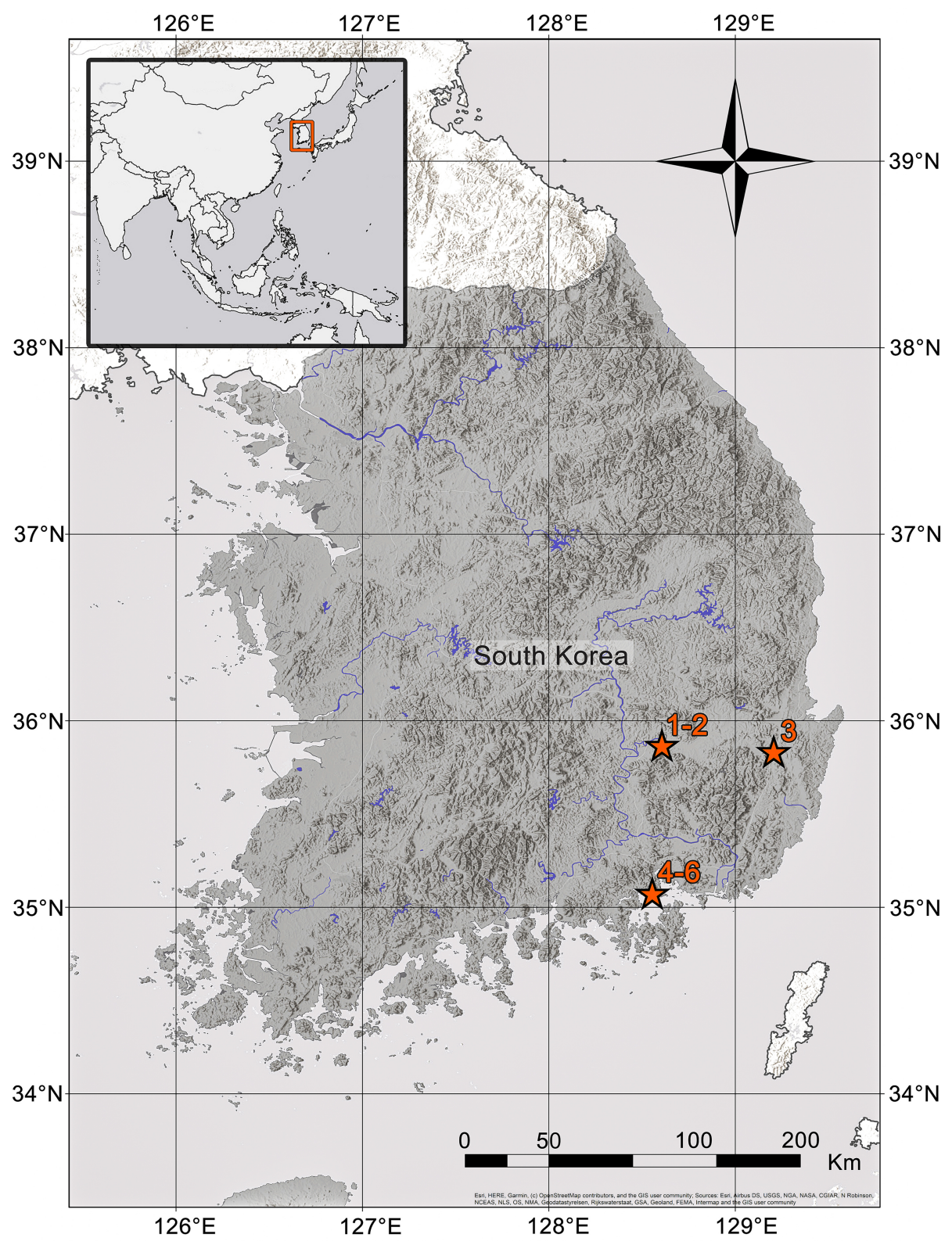

Fig. 1. Map of sampling sites. See Table 1 for the description of the sampling sites (1-6).

Table 1). Benthic samples were collected by roiling of surface bottom sediments and taking water with suspension of detritus. Interstitial water was taken from the small pits dug in the littoral sand. Periphyton samples were scraped off from the stones submerged in water and placed in tubes along with the surrounding water. All samples were placed into $50 \mathrm{ml}$ plastic tubes and transported to the laboratory at $4{ }^{\circ} \mathrm{C}$. Each sample was inoculated into a $60 \mathrm{~mm}$ Petri dish. One rice grain was added to each dish to stimulate bacteria growth. Samples were incubated at $20-22{ }^{\circ} \mathrm{C}$ in the dark, periodically examined with a light microscope. To obtain clonal cultures, single cells were picked out using a micropipette and transferred into Petri dishes with an inorganic medium and a food source.

For marine centrohelids, the cell culture of the flagellate Procryptobia sorokini (Zhukov, 1975) Frolov et al., 2001, grown in an artificial marine medium (RS-R11040, Red Sea) was used as prey. For freshwater centrohelids, the cell culture of flagellate Parabodo caudatus (Dujardin, 1841) Moreira et al., 2004, grown in a freshwater medium in mineral water (Aqua Minerale, PepsiCo) was used as prey. Both prey cultures were fed with Pseudomonas fluorescens Migula, 1895 bacterial culture. 
Table 1. Characteristics of sampling sites.

\begin{tabular}{|c|c|c|c|c|c|c|}
\hline No & Water body & Microbiotope & $\underset{\%}{\text { Salinity, }}$ & $\begin{array}{c}\text { Coordinates, } \\
\text { N, E }\end{array}$ & Date & Species \\
\hline 1 & \multirow{2}{*}{$\begin{array}{l}\text { Sincheon River (신천), Nakdong } \\
\text { River Basin (낙동강), Daegu } \\
\text { Metropolitan City (대구 광역시) }\end{array}$} & coastal benthos & - & \multirow{2}{*}{$\begin{array}{l}35^{\circ} 52^{\prime} 34.61^{\prime \prime} \\
128^{\circ} 36^{\prime} 22.54^{\prime \prime}\end{array}$} & \multirow{2}{*}{$\begin{array}{l}\text { May 8, } \\
2019\end{array}$} & Acanthocystis penardi \\
\hline 2 & & periphyton on stones & - & & & Pterocystis foliacea \\
\hline 3 & $\begin{array}{l}\text { Namcheon River (남천), Hyeongsan } \\
\text { River basin (형산강), Gyeongju } \\
\text { City (경주시) North Gyeongsang } \\
\text { Province (경상북도) }\end{array}$ & $\begin{array}{l}\text { coastal benthos among } \\
\text { macrophytes }\end{array}$ & - & $\begin{array}{l}35^{\circ} 49^{\prime} 44.96^{\prime \prime} \\
129^{\circ} 12^{\prime} 59.17^{\prime \prime}\end{array}$ & $\begin{array}{c}\text { May 11, } \\
2019\end{array}$ & Heterophrys-like organism \\
\hline 4 & \multirow{3}{*}{$\begin{array}{l}\text { Jeodo island (저도) Sea of Japan } \\
\text { (East Sea), Gubok-ri (구복리), } \\
\text { South Gyeongsang Province } \\
\text { (경상남도) }\end{array}$} & $\begin{array}{l}\text { interstitial water within } \\
\text { the sand and mollusk } \\
\text { shells on the littoral }\end{array}$ & 29 & \multirow{2}{*}{$\begin{array}{c}35^{\circ} 03^{\prime} 32.5^{\prime \prime} \\
128^{\circ} 33^{\prime} 43.18^{\prime \prime}\end{array}$} & \multirow{3}{*}{$\begin{array}{c}\text { May 10, } \\
2019\end{array}$} & Heterophrys-like organism \\
\hline 5 & & coastal benthos & 29 & & & $\begin{array}{l}\text { Choanocystis cordiformis ssp. } \\
\text { parvula }\end{array}$ \\
\hline 6 & & $\begin{array}{l}\text { interstitial water within } \\
\text { the sand on stony } \\
\text { litoral }\end{array}$ & 32 & $\begin{array}{l}35^{\circ} 03^{\prime} 09.86^{\prime \prime} \\
128^{\circ} 33^{\prime} 47.24^{\prime \prime}\end{array}$ & & $\begin{array}{l}\text { Raphidocystis sp.; Choanocystis } \\
\text { pelagica; Pterocystis } \\
\text { jongsooparkii sp. nov.; } \\
\text { Heterophrys-like organism }\end{array}$ \\
\hline
\end{tabular}

\section{MicRosCOPY}

An AxioScope A1 upright light microscope (Carl Zeiss, Germany) with DIC and phase contrast and water and oil immersion objectives $(63 \times$ and $100 \times)$, was used for observation of living cells. CKX41 inverted light microscope (Olympus, Japan) with phase contrast objectives $(20 \times, 40 \times)$ was used for preparing cell cultures. Light microscopic images were taken with an MC-12 camera (LomoMicrosystems, Russia).

Preparations for studying the skeletal elements were air-dried and carried out according to the described methods (Moestrup and Thomsen, 1980; Mikrjukov, 2002), and observed in transmission (JEM-1011, Jeol, Japan) and scanning (JSM6510 LV, Jeol, Japan) electron microscopes. The acceleration voltage was $80 \mathrm{kV}$ for TEM and 15-30 $\mathrm{kV}$ for SEM.

\section{Molecular PHYLOGENy}

Cells of a new species of centrohelid heliozoan (strain HMzp-2) were grown in a clonal culture and collected on a polycarbonate membrane filter (pore size $1 \mu \mathrm{m}$ ) using $60 \mathrm{ml}$ Syringe with Luer Lock (BD, USA) and Swinnex-25 mm filter holder (Millipore, USA). Genomic DNA was isolated using the MasterPure ${ }^{\mathrm{TM}}$ Complete DNA and RNA Purification Kit (Epicentre, Cat. No. MC85200). The 18S rRNAgene of strain HMzp-2 was amplified using the EconoTaq PLUS GREEN 2X Master Mix (Lucigen, Cat. No 30033-1) and universal eukaryotic primers (Cavalier-Smith et al., 2009):
25F (forward): 5'-CATATGCTTGTCTCAAA GATTAAGCCA-3'

1801R (reverse): 5'-TGATCCTTCTGCAGG TTCACCT-3'.

The PCR-program for amplification was as follows: initial denaturation at $95{ }^{\circ} \mathrm{C}$ for $3 \mathrm{~min}$, 35 cycles of $95{ }^{\circ} \mathrm{C}$ for $30 \mathrm{sec}, 52{ }^{\circ} \mathrm{C}$ for $30 \mathrm{sec}, 72$ ${ }^{\circ} \mathrm{C}$ for $1.5 \mathrm{~min}$, and a final extension at $72{ }^{\circ} \mathrm{C}$ for 5 min. Amplified DNA fragments were purified with QIAquick PCR Purification Kit (Quagen, Cat. No. 433160764). PCR products were sequenced by Sanger dideoxy sequencing (Evrogen; Moscow, Russia) in one replicate using 25F, 1801R, and two universal internal primers:

18SintF (forward): 5'- GGTAATTCCAGCTC CAATAGCGTA-3'

18SintR (reverse): 5'- GTTTCAGCCTTGC GACCATACT-3'.

The resulting sequence was assembled from 4 overlapping reads using the Geneous R6 6.0.6 program.

Forty-two centrohelid and five outgroup sequences were aligned by the L-INS-i algorithm in MAFFT version 7 (Online) (Katoh et al. 2005; Kuraku et al., 2013) and trimmed by using the Gappyout method in TrimAl (v. 1.3) (Capella-Gutierrez et al., 2009). The resulting alignments used to build the phylogenetic trees were 1553 bp in length for Fig. 6 and $1469 \mathrm{bp}$ for Fig. 7.

MrBayes v3.2.6 (Ronquist and Huelsenbeck, 2003) was run with four categories of Gamma-distributed among site rate variation and calculation of the proportion of invariable sites $(\mathrm{GTR}+\mathrm{I}+\mathrm{GAMMA} 4$ substitution model). The analysis was performed 
with four independent runs of four Metropoliscoupled Markov chains, sampled across 20 million generations, and summarized with a $50 \%$ burn-in. The maximum likelihood phylogeny was computed in IQ-TREE v1.5.4 (Nguyen et al., 2015) by using the best fit model (as determined by the in-built ModelFinder) and 1000 non-parametric bootstraps.

\section{Results}

Five species including one subspecies, one centrohelidian identified at the genus level, and Heterophrys-like organism were found in the studied sampling sites in South Korea (Table 1) and presented below according to the system of eukaryotes by Adl et al. (2019). A system of black circles “॰” was used to indicate levels of taxonomic ranks from high to low (the more circles, the lower the rank of the taxon). The morphological characteristics of the investigated cells of centrohelids are listed below.

Diaphoretickes Adl et al., 2012

- Haptista Cavalier-Smith, 2003

$\bullet$ Centroplasthelida Febvre-Chevalier et Febvre, 1984 2018

$\bullet \bullet$ Panacanthocystida Shishkin et Zlatogursky,

$\bullet \bullet \bullet$ Acanthocystida Cavalier-Smith et von der Heyden, 2007 emend. Shishkin et Zlatogursky, 2018

$\bullet \bullet \bullet$ Chalarothoracina Hertwig et Lesser, 1874 sensu Cavalier-Smith in Yabuki et al., 2012 emend. Shishkin et Zlatogursky, 2018

$\bullet \bullet \bullet \bullet \bullet$ Acanthocystidae Claus, 1874 emend. Shishkin et Zlatogursky, 2018

Acanthocystis penardi Wailes, 1925 (Fig. 2, A-C)

Material: Two cells from the sampling site No.1 (see Table 1).

Description: The surface of the cells is covered with plate and spine scales. Spine scales are 3.56$12.90 \mu \mathrm{m}$ in length. They consist of a circular basal plate $(1.01-1.92 \mu \mathrm{m}$ in diameter) and a cylindrical hollow shaft $(0.21-0.39 \mu \mathrm{m}$ in diameter). There are 4-8 (more often 5-6) marginal teeth on the tip of the shaft. Plate scales are elliptical, 3.90-5.05 Ч $2.32-3.31 \mu \mathrm{m}$, with a medial constriction and a slight medial thickening. The surface of plate scales is covered by numerous granules.

Remarks: The morphology and size of scales of the investigated cells are similar to the earlier descriptions. Some authors observed significantly longer spine scales: 15-20 $\mu \mathrm{m}$ (Nicholls, 1983), 8-33 $\mu \mathrm{m}$ ([as A. heterospina] Mikrjukov, 1993b), and 9-30 $\mu \mathrm{m}$ (Leonov, 2009).

Distribution: Freshwaters of Canada ([as $A$. heterospina] Nicholls, 1983), Estonia (Mikrjukov, 1993b), Russia (Mikrjukov, 1993a; Leonov, 2009, 2010; Leonov and Plotnikov, 2009; Leonov and Mylnikov, 2012; Prokina et al., 2017a, 2018), Mongolia (Kosolapova and Mylnikov, 2015), Chile (Dürrschmidt 1987a; Prokina and Mylnikov, 2019), Ethiopia (Prokina et al., 2017b), Nigeria (Wujek et al., 2007), Malaysia (Dürrschmidt, 1987a), Vietnam (Zagumyonnyi et al., 2020), and Ukraine ([as $A$. heterospina] Gaponova, 2008).

$\bullet \bullet \bullet \bullet \bullet$ Raphidocystidae Zlatogursky, 2018 Raphidocystis sp. (Fig. 2, D-F)

Material: Six cells from the sampling site No. 6 (see Table 1).

Description: The diameter of the dried cell is about $8 \mu \mathrm{m}$. The cell surface is covered with one type of circular or slightly oval plate scales, $1.24-1.87 \times$ $1.07-1.46 \mu \mathrm{m}$ in size. The inner part of the scales has a reticular texture with a slight medial thickening $(0.10-0.16 \times 0.04-0.09 \mu \mathrm{m}$ in size $)$. Scales are bordered by peripheral dense rim $0.05-0.13 \mu \mathrm{m}$ in diameter. The length to width ratio of scales is 1.09-1.51.

Remarks: The scales of the studied cells are similar in structure to the scales of representatives of the genus Raphidocystis (R. tubifera Penard, 1904; R. ambigua (Penard, 1904) Zlatogursky, 2018; $R$. symmetrica (Penard, 1904) Zlatogursky, 2018) by the presence of an internal reticular surface texture, and a well-defined marginal rim. However, scales of studied heliozoan can be distinguished from the listed species by very small sizes of scales, circular shape and the presence of a slight medial thickening, as well as the absence of other types of scales.

$\bullet \bullet$ Pterocystida Cavalier-Smith et von der Heyden, 2007, emend. Shishkin et Zlatogursky, 2018

$\bullet \bullet \bullet$ Raphidista Shishkin et Zlatogursky, 2018

$\bullet \bullet \bullet$ Choanocystidae Cavalier-Smith et von der Heyden, 2007

Choanocystis pelagica (Ostenfeld, 1904) Mikrjukov, 1994 (Fig. 3, A-I)

Material: Four cells from the sampling site No. 6 (see Table 1).

Description: The diameter of living cells is $23.8-$ 

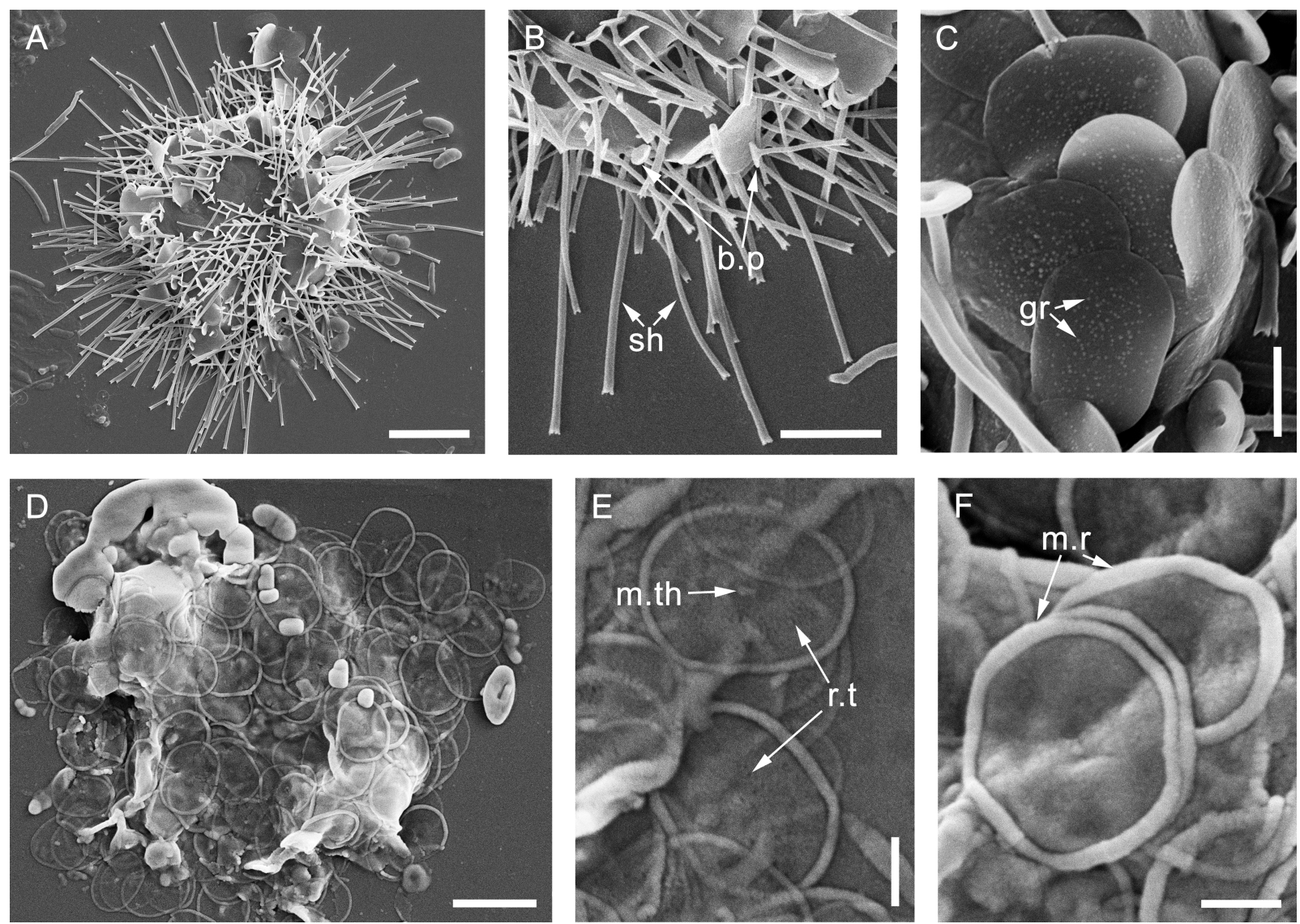

Fig. 2. Morphology of observed scales of Acanthocystis penardi and Raphidocystis sp. (SEM). A-C - Acanthocystis penardi: A - general view of the dried cell; B - spine scales; C - plate scales; D-F - Raphidocystis sp.: D general view of the dried cell; E, F - plate scales. Abbreviations: b.p - basal plate; gr - granules; m.r - marginal rim; m.th - medial thickening; r.t - reticular texture; sh - shaft. Scale bars: A - $10 \mu \mathrm{m} ; \mathrm{B}-5 \mu \mathrm{m} ; \mathrm{C}, \mathrm{D}-2$ $\mu \mathrm{m} ; \mathrm{E}, \mathrm{F}-0.5 \mu \mathrm{m}$.

$25.5 \mu \mathrm{m}$. The surface of the cell is covered with spine and plate scales. Spine scales consist of a hollow cylindrical shaft and a heart-shaped basal plate. The shaft is $4.05-9.66 \mu \mathrm{m}$ in length and $0.25-0.40 \mu \mathrm{m}$ in width, curved proximally, and pointed distally. The basal plate is $1.75-2.15 \mu \mathrm{m}$ in width. Some basal plates of spine scales have fringed marginal rim (Fig. $3, \mathrm{~F}-\mathrm{G})$. Plate scales are $3.32-6.55 \times 2.35-3.89 \mu \mathrm{m}$, elliptic to pear-shaped, with a medial constriction and a slight medial thickening $(0.13-1.17 \times 0.03-$ $0.18 \mu \mathrm{m})$. No papillae were found on the surface of the scales.

Remarks: Ostenfeld (1904) described this species as Acanthocystis pelagica using light microscopic data. Mikrjukov (1994a) presented this species with emendation of its diagnosis based on electron microscopic data and transferred this species to genus Choanocystis. In another study, Mikrjukov (1994b) presented a description of a similar orga- nism, attributing it to Ch. pelagica and supplementing the diagnosis. The cells observed by Mikrjukov are different from the ones observed by Ostenfeld (1904) by 4 to 5 times shorter spine scales and twice shorter plate scales. Detailed morphometric data on these specimens are presented in Table 2. According to such significant differences in the size of the scales, we assume that Mikrjukov and Ostenfeld described two different species. In addition, there are significant differences in the morphology of cell scales described by Mikrjukov (1994a, 1994b), which were isolated from the Moscow State University marine aquarium and from the Velikaya Salma Strait of the White Sea. These two organisms can belong to two different species, which was rightly pointed out by Cavalier-Smith and von der Heyden (2007). The molecular data are needed to resolve this uncertainty. Our morphological observations correspond to the description of Ch. pelagica from 

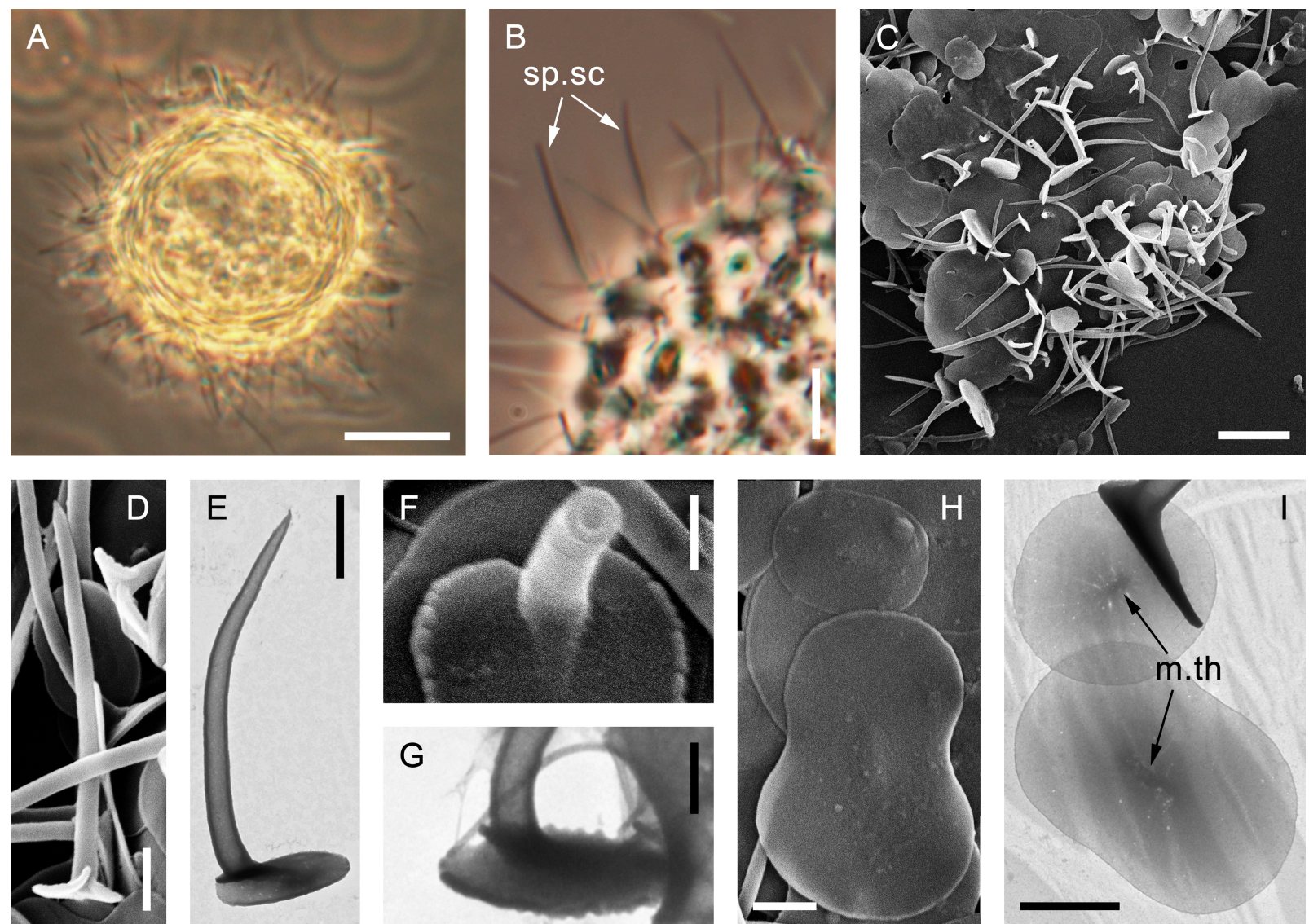

G
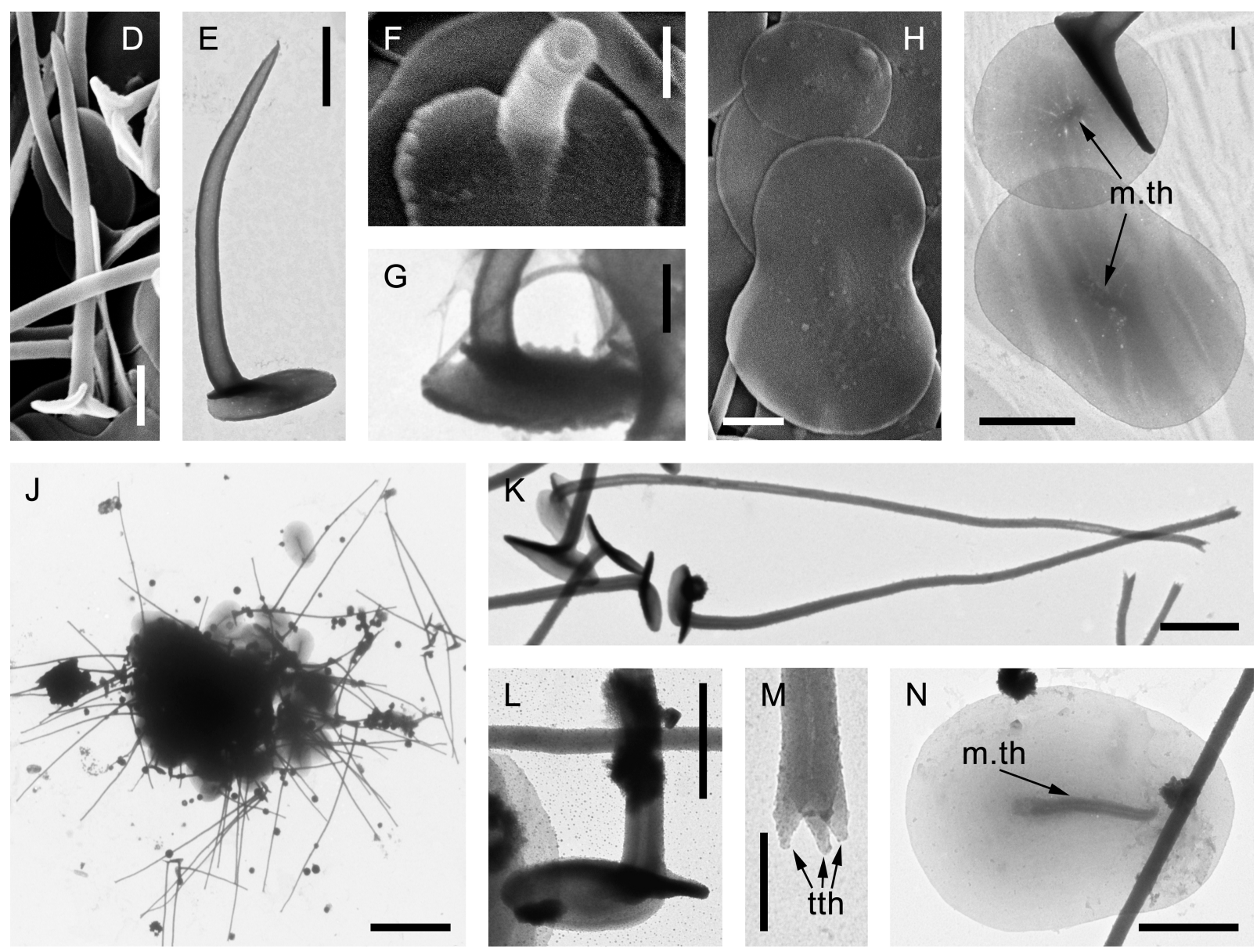

Fig. 3. Morphology of living cells and scales of genus Choanocystis (A, B - PhC; C, D, F, H - SEM; E, G, I-N - TEM). A-I - Ch. pelagica: A, B - general view of the living cell; C - general view of the dried cell; D, E - spine scales; F, G - basal plate of the spine scales; H, I - plate scales; J-N - Ch. cordiformis ssp. parvula: $\mathrm{J}$ - general view of the dried cell, $\mathrm{K}$ - spine scales; $\mathrm{L}$ - basal plate of the spine scale; $\mathrm{M}$ - distal tip of the spine scales; N - plate scale. Abbreviations: sp.sc - spine scales; th - teeth; for explanation of other symbols see Fig. 2. Scale bars: A, J $-10 \mu \mathrm{m} ; \mathrm{B}, \mathrm{C}-5 \mu \mathrm{m} ; \mathrm{D}, \mathrm{E}, \mathrm{H}, \mathrm{I}, \mathrm{K}, \mathrm{N}-1 \mu \mathrm{m} ; \mathrm{F}, \mathrm{G}, \mathrm{L}-0.5 \mu \mathrm{m} ; \mathrm{M}-0.1 \mu \mathrm{m}$. 
Table 2. Comparison of morphometric parameters of Choanocystis pelagica.

\begin{tabular}{|c|c|c|c|c|c|c|c|c|}
\hline \multirow{2}{*}{ Locality } & \multirow{2}{*}{$\begin{array}{c}\text { Diameter } \\
\text { of cells, } \\
\mu \mathrm{m}\end{array}$} & \multicolumn{3}{|c|}{ Spine scales } & \multicolumn{3}{|c|}{ Plate scales } & \multirow{2}{*}{ Reference } \\
\hline & & $\begin{array}{c}\text { Shaft } \\
\text { length, } \mu \mathrm{m}\end{array}$ & $\begin{array}{c}\text { Basal plate, } \\
\mu \mathrm{m}\end{array}$ & $\begin{array}{c}\text { Diameter } \\
\text { of shaft, } \mu \mathrm{m}\end{array}$ & $\begin{array}{l}\text { Length, } \\
\mu \mathrm{m}\end{array}$ & $\begin{array}{c}\text { Width, } \\
\mu \mathrm{m}\end{array}$ & Morphological features & \\
\hline North Sea & ca. 40 & $40-50$ & $\stackrel{-}{\text { Discoid base }}$ & - & ca. 10 & - & $\begin{array}{l}\text { Consist of two triangular } \\
\text { parts connected by a } \\
\text { narrow piece (dumbbell- } \\
\text { shaped) }\end{array}$ & Ostenfeld, 1904 \\
\hline $\begin{array}{l}\text { Marine aquari- } \\
\text { um of Moscow } \\
\text { State University }\end{array}$ & $25-49$ & са. 7 & $\begin{array}{c}1.6-1.8 \\
\text { Heart- } \\
\text { shaped base }\end{array}$ & 0.4 & $4-5$ & $2.0-2.5$ & $\begin{array}{l}\text { Dumbbell-shaped, } \\
\text { textureless, with medial } \\
\text { constriction }\end{array}$ & Mikrjukov, 1994a \\
\hline White Sea & $23-25$ & $6.0-12.6$ & $\begin{array}{c}1.6-1.8 \\
\text { Heart- } \\
\text { shaped base }\end{array}$ & $0.30-0.35$ & 4.5 & 2.1 & $\begin{array}{l}\text { Elliptical, with a small } \\
\text { medial thickening and } \\
\text { papillae }\end{array}$ & Mikrjukov, 1994b \\
\hline $\begin{array}{l}\text { Sea of Japan } \\
\text { (East Sea) }\end{array}$ & 23.8 & $4.05-9.66$ & $\begin{array}{l}\text { 1.75-2.15; } \\
\text { Heart- } \\
\text { shaped base }\end{array}$ & $0.25-0.40$ & $\begin{array}{l}3.32- \\
6.55\end{array}$ & $\begin{array}{c}2.35- \\
3.89\end{array}$ & $\begin{array}{l}\text { Elliptical or pear-shaped, } \\
\text { with a medial constriction } \\
\text { and a slight medial } \\
\text { thickening. Without } \\
\text { granules }\end{array}$ & This article \\
\hline
\end{tabular}

marine aquarium (Mikrjukov, 1994a).

Kosolapova and Mylnikov (2015) described Choanocystis aff. pelagica from freshwaters of Mongolia. However, this organism differs from Choanocystis pelagica by the presence of five teeth at the apex of the shaft and habitation in freshwater.

Distribution: Marine aquarium of Lomonosov Moscow State University (Mikrjukov, 1994a).

Choanocystis cordiformis ssp. parvula Dürrschmidt, 1987 (Fig. 3, J-N)

Material: One cell from the sampling site No. 5 (see Table 1).

Description: The surface of the cell is covered with spine and plate scales. Spine scales consist of a hollow cylindrical shaft and a heart-shaped basal plate. The shaft is straight and slightly tapering in the distal part and ends with three teeth. The length of the shaft is $4.26-14.45 \mu \mathrm{m}$, the diameter of the shaft is $0.11-0.14 \mu \mathrm{m}$. The basal plate is $0.92-1.45$ $\mu \mathrm{m}$ in diameter. Ovate plate scales are 3.34-3.40 $\times$ 2.03-2.35 $\mu \mathrm{m}$, with smooth surface, thin marginal rim, and a well-developed medial thickening $(1.55-1.71 \times 0.14-0.20 \mu \mathrm{m})$.

Remarks: The studied organism is most similar to the subspecies Choanocystis cordiformis parvula described by Dürrschmidt (1987a). The size of the cell in the original description is about $10 \mu \mathrm{m}$. Spine scales are straight and slightly sharpened, $6-8 \mu \mathrm{m}$ in length, with 2-4 apical teeth. Plate scales are smooth, 2.3-3.2 × 1.5-1.8 $\mu \mathrm{m}$. Mikrjukov (2002) considers Ch. cordiformis ssp. parvula as the junior synonym of Ch. perpusilla (Petersen et Hansen, 1960) Siemensma, 1991. However, Ch. perpusilla is distinguished by the presence of only two teeth at the apex of the spine scales (Croome et al., 1987; Vørs, 1992; Mikrjukov, 1993b; Tong et al., 1997; Leonov and Plotnikov, 2009; Leonov, 2010; Shatilovich et al., 2010; Leonov and Mylnikov, 2012; Prokina and Mylnikov, 2019; Prokina et al., 2020).

Distribution: Freshwaters of Sri Lanka (Dürrschmidt, 1987a).

$\bullet \bullet \bullet$ Pterista Shishkin et Zlatogursky, 2018

$\bullet \bullet \bullet \bullet$ Pterocystidae Cavalier-Smith et von der Heyden, 2007

Pterocystis foliacea (Dürrschmidt, 1985) Siemensma, 1991 (Fig. 4)

Material: Seventeen cells from the sampling site No. 2 (see Table 1).

Description: The diameter of living cells is 8.82$14.10 \mu \mathrm{m}$. The axopodia are two times longer than the cell diameter. The surface of the cells is covered by plate and spine scales. Spine scales are leafshaped, 2.66-5.38 $\mu \mathrm{m}$ in length. They consist of a cylindrical shaft associated with textureless lateral and basal wings. The shaft is $0.13-1.17 \mu \mathrm{m}$ in length, truncated distally. At the base, basal and lateral wings are stretched into a small "stalk" 0.54-0.91 $\mu \mathrm{m}$ in length and $0.46-1.17 \mu \mathrm{m}$ in width. The lateral wings stretching along the entire length of the shaft, gradually narrowing towards the distal tip. The spine 

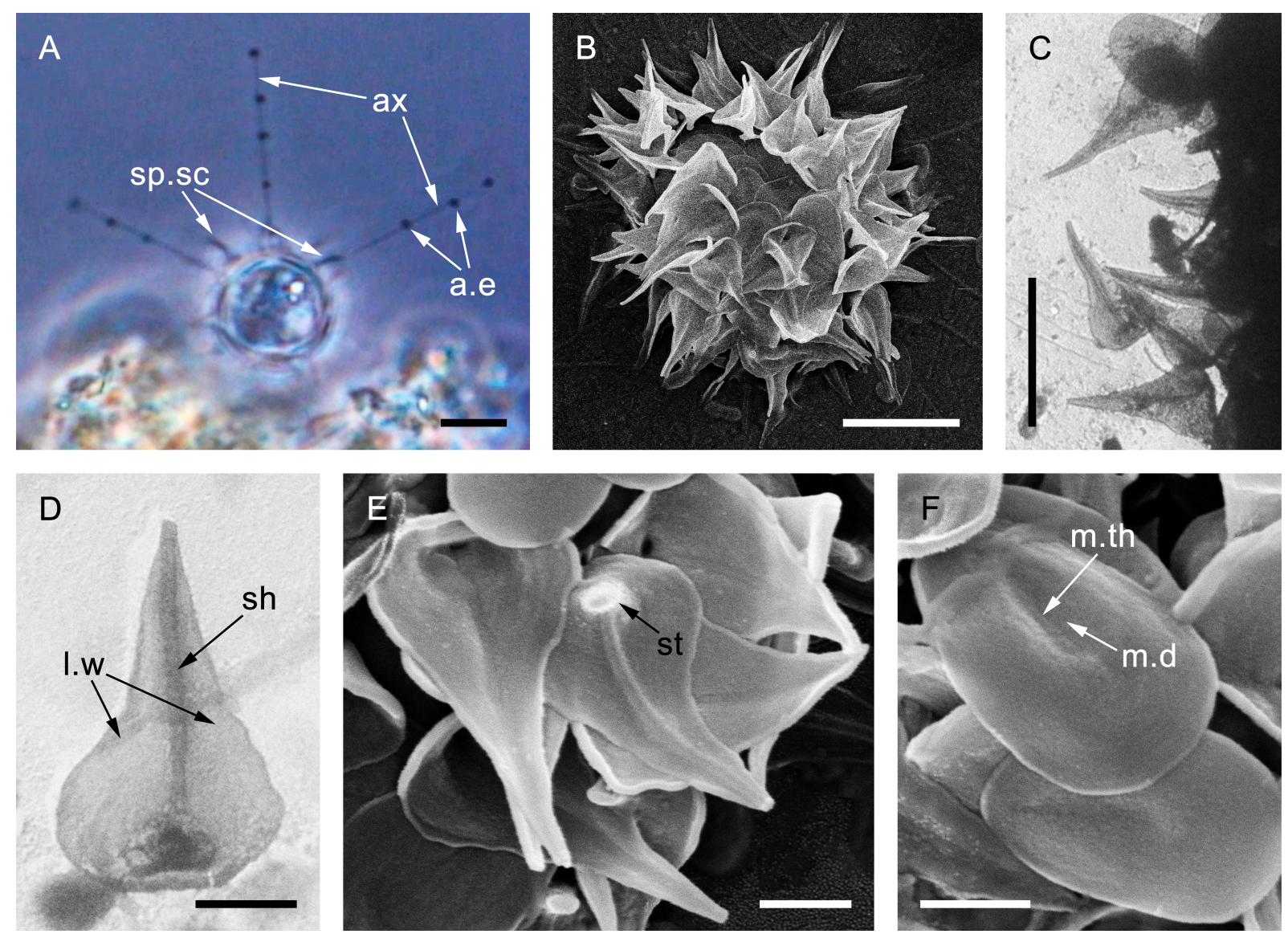

Fig. 4. Morphology of living cells and scales of Pterocystis foliacea (A - PhC; B, E, F - SEM; C, D - TEM). A - General view of the living cell; B - general view of the dried cell; $\mathrm{C}-\mathrm{E}$ - spine scales; F - plate scales. Abbreviations: a.e - axopodial extrusomes; ax - axopodia; l.w - lateral wing; m.d-medial depression; st - stalk; for explanation of other symbols see Figs $2-3$. Scale bars: A $-10 \mu \mathrm{m}$; B, C $-5 \mu \mathrm{m}$; D-F $-1 \mu \mathrm{m}$.

scales are 1.59-2.88 $\mu \mathrm{m}$ wide in the widest part. Oval textureless plate scales are $2.50-4.13 \times 1.54-2.95$ $\mu \mathrm{m}$ and possess a medial depression with a medial thickening at the bottom, and a poorly expressed marginal rim.

Remarks: Morphology of observed skeletal elements corresponds to previous descriptions of specimens found in freshwater biotopes, especially those from Russia and Ukraine (Gaponova, 2008; Prokina et al., 2018). Organisms observed in saline water habitats (Plotnikov and Gerasimova, 2017; Prokina et al., 2019) with markedly different morphology (narrowed and waved spine scales with curved tips) probably belong to different species.

Distribution: Freshwaters of Chile (Dürrschmidt, 1985; Prokina and Mylnikov, 2019), Nigeria (Wujek and Ogundipe, 2002), Ukraine (Gaponova, 2008), Russia (Prokina et al., 2018), India (Wujek and Saha, 2006), Vietnam (Prokina et al., 2020),
Australia (Croome, 1987), Japan and Sri Lanka (Dürrschmidt, 1987b)

Pterocystis jongsooparkii sp. nov. (Fig. 5)

Material: Nine cells from the sampling site No. 6 (see Table 1).

Diagnosis: The diameter of living cells is 8.2$10.6 \mu \mathrm{m}$. The axopodia are two times longer than the cell diameter. Skeletal elements are represented by spine and plate scales. Spine scales consist of a shaft and trapezoidal base $(1.44-2.23 \mu \mathrm{m}$ in the wide proximal part) formed by lateral and basal wings. The lateral wings are $1.60-2.43 \mu \mathrm{m}$ in length. They gradually taper towards the shaft and abruptly terminate at the middle part of the shaft, forming "shoulders". The shaft is not tapered, straight, and smooth in the distal part, 3.12-4.60 $\mu \mathrm{m}$ in length, $0.13-0.27 \mu \mathrm{m}$ in diameter. There are 

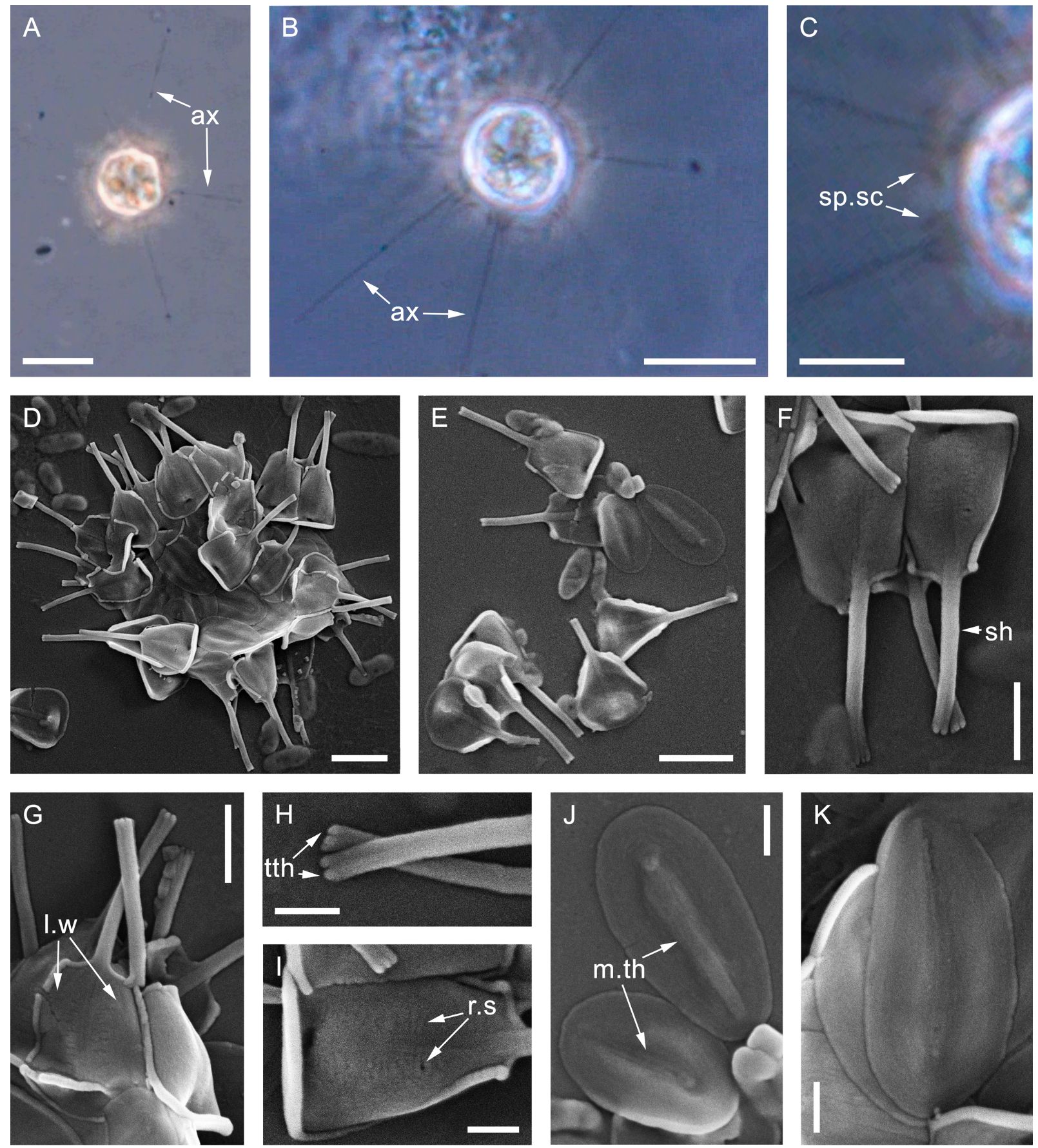

Fig. 5. Morphology of living cells and scales of Pterocystis jongsooparkii sp. nov. (A-C - PhC; D-K - SEM). A-C - General view of the living cell; D - general view of the dried cell; E - scales of destroyed cell; F, $\mathrm{G}$ - spine scales; $\mathrm{H}$ - distal tips of the spine scales; I - proximal part of the spine scale; J, $\mathrm{K}$ - plate scales. Abbreviations: r.s - radial slits; for explanation of other symbols see Figs 2-4. Scale bars: A, B $-10 \mu \mathrm{m}$; C -5 $\mu \mathrm{m} ; \mathrm{D}, \mathrm{E}-2 \mu \mathrm{m} ; \mathrm{F}, \mathrm{G}-1 \mu \mathrm{m} ; \mathrm{H}-\mathrm{K}-0.5 \mu \mathrm{m}$. 
five small rounded marginal teeth at the apex of the shaft. The proximal half of the shaft is connected with basal and lateral wings and curved, forming a scoop-like structure. The inner surface of the lateral wings contains about $10-15$ parallel transverse slits. The sides of lateral wings are bent out, and form a marginal rim $0.07-0.12 \mu \mathrm{m}$ in diameter.

Plate scales are oval, 2.18-2.98 $\times 1.19-1.61 \mu \mathrm{m}$, with a medial thickening $1.31-2.21 \times 0.25-0.39 \mu \mathrm{m}$. Marginal rim varies from almost not pronounced $(0.04 \mu \mathrm{m}$ in diameter) to rather wide $(0.11 \mu \mathrm{m}$ in diameter). The length to width ratio of the plate scales is $1.63-2.13$.

Cysts formation is not recorded.

Remarks: Pterocystis jongsooparkii sp. nov. (strain HMzp-2) possesses some significant morphological peculiarities. Among the species of Pterocystis and Raineriophrys, the studied heliozoan is most similar to Pterocystis anapoda Siemensma et Roijackers, 1988 by the trapezoidal base of spine scales. However, P. anapoda is characterized by spine scales that are two times longer, 6.5-14.7 $\mu \mathrm{m}$ (Siemensma and Roijackers, 1988a; Prokina and Philippov, 2019). Distal tips of spine scales of $P$. anapoda are truncated, without any teeth, while our strain has five small rounded marginal teeth. Scales of $P$. jongsooparkii are also similar to those of Raineriophrys fortesca (Nicholls, 1983; Mikrjukov, 1999). Both species are characterized by the presence of marginal teeth on the non-tapering distal tip of the shaft, and they are similar in terms of the presence of the radial slits on the inner lateral wings as well as in the shape and size of plate scales. However, spine scales of $R$. fortesca are usually longer (up to 24.0 $\mu \mathrm{m})$. Their lateral wings are triangular or circular in shape; the radial ribs are present on the basal wings.

Etymology: named after Prof. Jong Soo Park, who contributed significantly to the investigations of marine and hypersaline protists and organized the field survey.

Type locality: Interstitial water within the sand on stony littoral of Jeodo island shore (저도), the Sea of Japan (the East Sea) (Gubok-ri (구복리), South Gyeongsang Province (경상남도)), Republic of Korea, 35 $03^{\prime} 09.86^{\prime \prime} \mathrm{N}, 128^{\circ} 33^{\prime} 47.24^{\prime \prime} \mathrm{E}$.

Hapantotype: Preparation for SEM No. 1-HM zp-2 is kept in the laboratory of Microbiology at the Papanin Institute for Biology of Inland Waters RAS (Borok, Russia).

Type sequence: The $18 \mathrm{~S}$ rRNA gene sequence has been deposited into GenBank (NCBI) under accession number: MW298843.
ZooBank Registration: LSID: urn:lsid:zoobank. org:act:83E80699-5E24-4521-8198-79D943129E46.

\section{Phylogenetic placement}

Centrohelid heliozoans are subdivided into orders Panacanthocystida and Pterocystida on the SSU rDNA phylogenetic tree (Fig. 6). The studied strain is placed within the clade Pterista of Pterocystida. $P$. jongsooparkii forms a separate phylogenetic lineage in an unresolved trichotomy with Pterocystidae $\mathrm{C}$ and the clade $(\mathrm{BPP}=0.98, \mathrm{ML}=51)$ uniting representatives of Pterocystidae B, Heterophryidae, and environmental sequence Env H10.4 (AY749549). Monophyletic taxa Pterocystidae B and Heterophryidae group together with high BPP and low ML support (Fig. 6). Apparently, Pterocystis jongsooparkii forms previously undescribed phylogenetic lineage of Pterista. Within the environmental sequences, $P$. jongsooparkii groups together with Env H30.9 (AY749517) sequence with high support $(\mathrm{BPP}=1.00, \mathrm{ML}=99)$ (Fig. 7). Environmental sequence Env H13.6 (AY749535) forms a sister lineage to this clade on Bayesian tree, albeit with low support $(\mathrm{BPP}=0.52$, Fig. 7$)$.

\section{Heterophrys-like organism(s) (Fig. 8)}

Material: Three cells from sampling site No. 3, seven cells from sampling site No. 4, and one cell from sampling site No. 6 (see Table 1).

Description of marine isolates: The diameter of observed cells is $3.82-6.46 \mu \mathrm{m}$. Axopodia are 3.5 times longer than the cell diameter. Cells are covered with organic spindle-shaped spicules $1.20-2.52 \mu \mathrm{m}$ in length and $0.015-0.031 \mu \mathrm{m}$ in width. Spicules are located irregularly on the cell surface. The basal part of the spicules is probably buried into the organic layer. Spicules are slightly flattened and twisted along the longitudinal axis, with both pointed tips.

Description of freshwater isolates: The diameter of dried cells is $14.91-17.00 \mu \mathrm{m}$. Organic spindleshaped spicules are 5.98-9.26 $\mu \mathrm{m}$ in length and $0.11-0.13 \mu \mathrm{m}$ in width. Spicules are located strictly radially on the cell surface. The shape of the spicules is similar to that described above.

Remarks: Examined marine and freshwater cells are significantly different. Specimens from marine waters (sampling points Nos. 4 and 6) are characterized by smaller sizes of cells and shorter spindle-shaped spicules. In addition, spicules of marine specimens are oriented irregularly on the cell surface. Spicules of freshwater specimens are oriented strictly radially on the cell surface. 


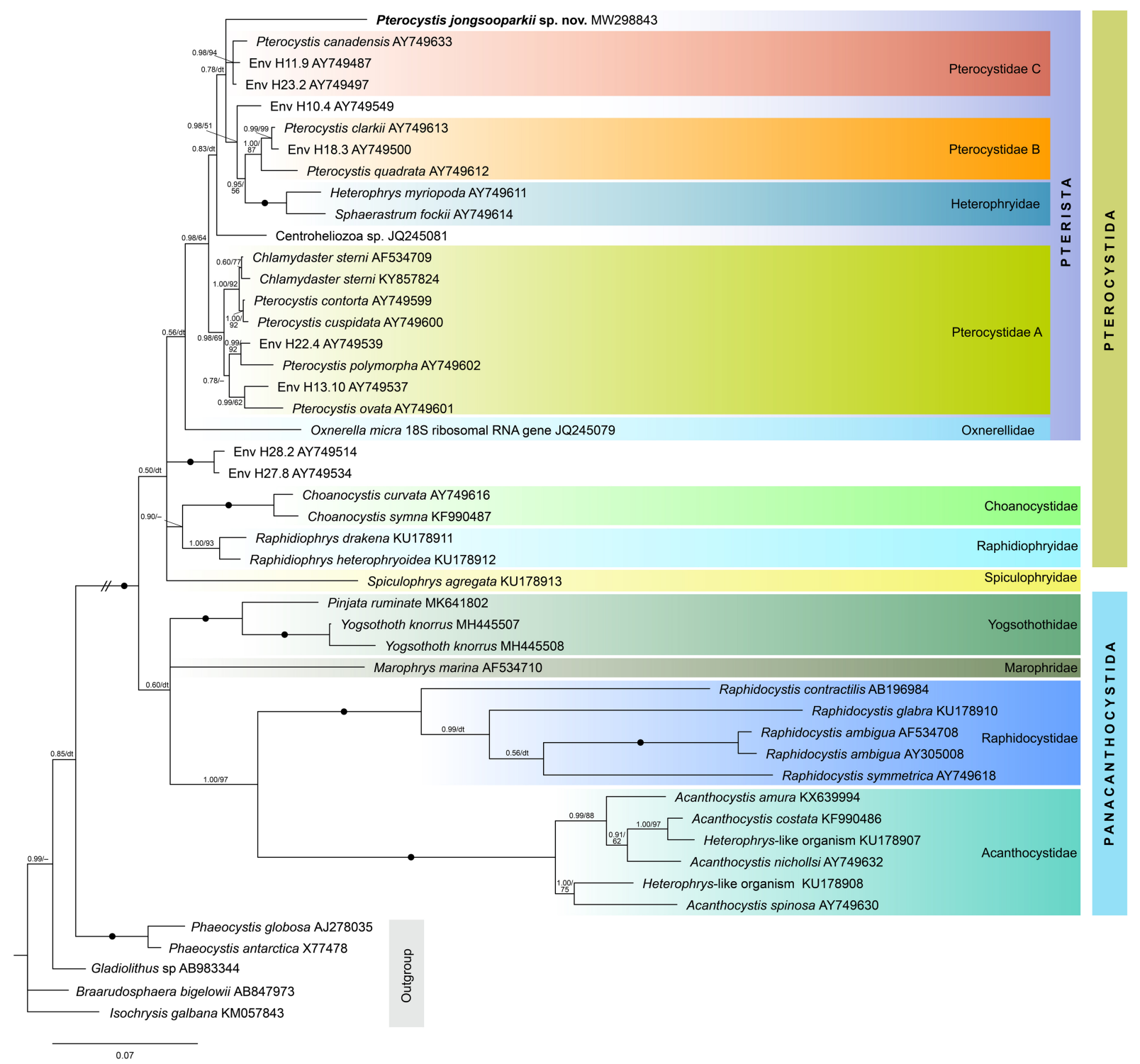

Fig. 6. Phylogenetic tree generated from Bayesian analysis of small subunit ribosomal RNA gene sequences of 42 centrohelids and 5 outgroup species. The branch lengths denoted by double slash (//) were shortened (10Ч) to improve visualization. Bayesian posterior probabilities (BPP) and Maximum Likelihood (ML, NT+R4 model) bootstrap values are indicated at branches (values $>0.5 />50$ are shown); black filled circles indicate values of BPP $=1.00$ and ML bootstrap $=100 \%$; dt - different topology. Sequence generated in this study is shown in bold.

Centrohelids with organic spindle-shaped spicules, such as Heterophrys, Marophrys, Sphaerastrum, and Spiculophrys, are morphologically indistinguishable. Phylogenetic analysis of $18 \mathrm{~S}$ rRNA genes showed the presence of at least six unrelated lineages of Heterophrys-like organisms in different parts of the centrochelid tree (Zlatogursky, 2016). Besides, the presence of dimorphism in the life cycle has been described in at least two genera of centrohelids (Raphidiophrys, Raphidocystis). At one of the life cycle stages, cells can lose siliceous scales and carry only organic spicules (Zlatogursky et al., 2018; Drachko et al., 2020). Thereby, the observed organisms can represent several known or new centrohelid species, which can only be identified using molecular methods and observations in clonal cultures. 


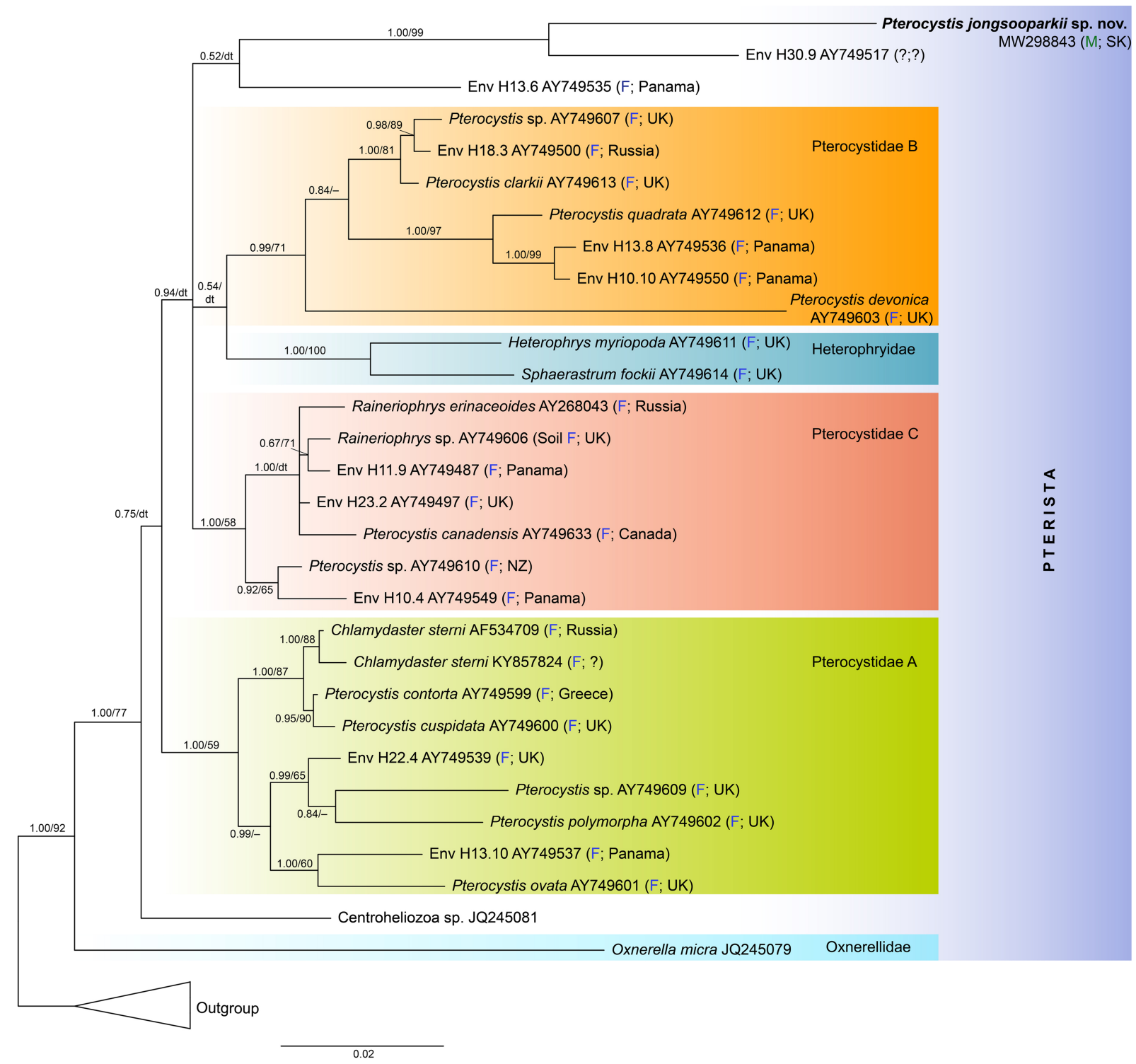

Fig. 7. Phylogenetic tree generated from Bayesian analysis of small subunit ribosomal RNA gene sequences of 30 Pterista and 3 outgroup species. Bayesian posterior probabilities (BPP) and Maximum Likelihood (ML, $\mathrm{NT}+\mathrm{R} 3$ model) bootstrap values are indicated at branches (values $>0.5 />50$ are shown); $\mathrm{dt}-$ different topology. Sequence generated in this study is shown in bold. Abbreviations: F - freshwater environment; $\mathrm{M}$ - marine environment; SK - South Korea; NZ - New Zealand; UK - United Kingdom. Outgroup: Raphidiophrys drakena KU178911, Choanocystis curvata AY749616, Yogsothoth knorrus MH445507.

\section{Discussion}

The cover elements (scales and spicules) of centrohelid heliozoans from two river sites and one marine site in South Korea have been examined. Representatives of four genera and four families (Acanthocystidae, Choanocystidae, Pterocystidae, and Raphidocystidae) have been identified. All the species found are apparently new to South
Korea, due to the absence of any relevant research in this region to date. One new species, Pterocystis jongsooparkii sp. nov., was described. The genera Choanocystis and Pterocystis were represented by two species each. The rest of the genera was represented by a single species.

Five species were identified in marine waters, while three species were found in freshwaters. Heterophrys-like organisms were observed in both 

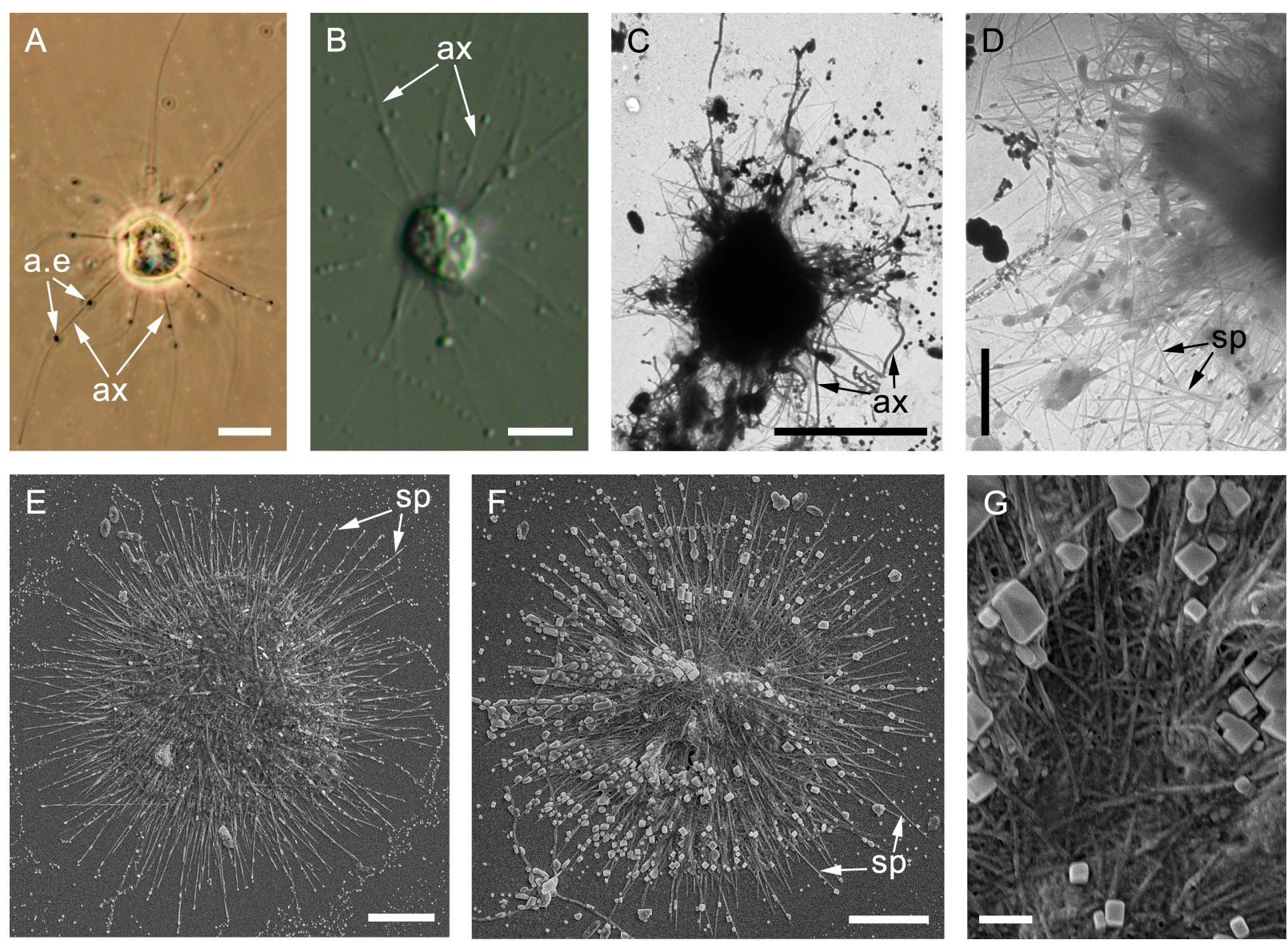

Fig. 8. Morphology of living cells and spicules of Heterophrys-like organisms (A - PhC; B - DIC; C, D - TEM; E-G - SEM). A-D - Specimens of Heterophrys-like organisms from marine biotopes (Nos. 4 and 6, Table 1): A, B - general view of the living cells; $\mathrm{C}$ - general view of the dried cell; D - spicules; E-G - specimens of Heterophrys-like organisms from freshwater biotopes (No. 3, Table 1): E, F - general view of the dried cells; $\mathrm{G}$ - spicules. Abbreviations: sp - spicules; for explanation of other symbols see Fig.4. Scale bars: A-C, E, F-5 $\mu \mathrm{m} ; \mathrm{D}, \mathrm{G}-1 \mu \mathrm{m}$.

marine and freshwater habitats: once in a freshwater sample from Namcheon River, Gyeongju City, and two times in marine samples from the Sea of Japan (East Sea). However, due to the assumed dimorphism of their life cycle, Heterophrys-like organisms can represent several different centrohelid species.

Two of the identified species, Acanthocystis penardi and Pterocystis foliacea, are known from all parts of the Globe (Northern, Southern, Western, and Eastern hemispheres) and thus can be considered cosmopolitan. Two other species, Choanocystis pelagica and Ch. perpusilla ssp. parvula, as well as the new species, Pterocystis jongsooparkii sp. nov., are known only from the Northern and Eastern hemi-spheres (Dürrschmidt, 1987a; Mikrjukov, 1994a, b). However, due to the poor knowledge of centrohelids and lack of data for many regions, we believe that the distributional ranges of these species will extend with further research.

Two of the observed species, Acanthocystis penardi and Pterocystis foliacea, can be considered exclusively freshwater. Acanthocystis penardi was previously found only in freshwater samples, although it is quite common. In our study, we also found it in a freshwater biotope. Even though Pterocystis foliacea was found twice in saline biotopes (Plotnikov and Gerasimova, 2017; Prokina et al., 2019), it can still be considered as a freshwater species, since forms from saline waters are characterized by extremely different morphology. Thereby, specimens from saline continental and marine biotopes may represent another, so far undescribed species 
of centrohelids. This assumption can be confirmed or disproved only with the study of molecular phylogenetics.

Centrohelid Choanocystis cordiformis ssp. parvula was originally described from a freshwater pond in Sri Lanka. We observed it in marine samples; this finding expands its ecological limits and may indicate the euryhalinity of this subspecies. In this study, Choanocystis pelagica was observed in samples from the Sea of Japan; therefore, it can be considered marine since it had been previously found only in saline waters.

The scale morphology of the studied species generally fits the known descriptions. However, some differences were found. Thus, Raphidocystis sp. was identified only to a genus level. It can be distinguished from all known Raphidocystis species by the presence of only one type of very small almost circular plate scales with a slight medial thickening. It is necessary to study the clonal cultures to clarify the relationships of this species with other centrohelids. The described new species of centrohelid heliozoans possesses a unique morphology of scales, easily distinguishable from scales of all previously known species. The topology of the main clades of centrohelids on phylogenetic tree (Fig. 6) generally corresponds to that in the works of other authors (CavalierSmith and von der Heyden, 2007; Zlatogursky, 2016; Shishkin et al., 2018). Spiculophryidae forms polytomy without support with Pterista, Raphidiophryidae, Choanocystidae, and a group of environmental sequences. Determining the position of Spiculophryidae has also been challenging in previous works (Zlatogursky, 2016; Shishkin et al., 2018). Environmental sequences H28.2 (AY7 49514) and H27.8 (AY749534) of uncertain phylogenetic position were placed as a sister group to Choanocystidae in previous phylogenetic reconstruction (Cavalier-Smith and von der Heyden, 2007) with a larger number of sequences in the dataset.

Three clades uniting representatives of the genus Pterocystis (Pterocystidae A, Pterocystidae B, Pterocystidae C) and Heterophryidae are grouped within Pterista, which may also include Oxnerellidae and Centroheliozoa sp. JQ245081. Clade Pterocystidae A forms a sister group to other pterocystids and heterophryids.

Environmental sequence H10.4 (AY749549) forms a sister lineage to the grouping of wellsupported clade Pterocystidae B and Heterophryidae, albeit without strong ML support on the tree of centrohelids (Fig. 6). However, this sequence is placed within Pterocystidae C on the tree of Pterista (Fig. 7) and according to other phylogenetic reconstructions (Cavalier-Smith and Chao, 2012; Zlatogursky, 2016). Relationships between Heterophryidae and Pterocystidae B are not well resolved so far.

In addition to Pterocystis canadensis (AY749633), two sequences of unidentified centrohelids and three environmental sequences (AY749487, AY749497, AY749549), the well-supported clade Pterocystidae $\mathrm{C}$ also includes a sequence of Raineriophrys erinaceoides (AY268043). This sequence was presented by Nikolaev et al. (2004). It was obtained from a clonal culture isolated by A.P. Mylnikov and kept at the culture collection of the Papanin Institute for the Biology of Inland Waters of the Russian Academy of Sciences (IBIW RAS). Unfortunately, this culture was lost, and the article by Nikolaev et al. (2004) did not provide morphological images of the clone. However, the close similarity of the sequences of $P$. canadensis (AY749633) and R. erinaceoides (AY268043) together with high similarity of the available morphological data on $R$. erinaceoides and $P$. canadensis allow us to assume that Pterocystidae C clade does indeed include representatives of the genus Raineriophrys.

The isolation source of the closely related to $P$. jongsooparkii environmental sequence Env H30.9 (AY749517) is unknown. According to Gerasimova et al. (2020), Env H30.9 formed a well-supported clade with a cluster of seven OTUs obtained from continental saline and brackish water bodies with salinity 2-78\%o (Orenburg Region, Russia).

A large number of environmental sequences representing the centrohelids without accompanying morphological data branch between the described clades in accordance with phylogenetic trees of other authors (Cavalier-Smith and Chao, 2012; Shishkin et al., 2018).

One of the main problems in resolving the relationships between centrohelid taxa is the lack of sufficient molecular data for morphologically characterized species and genera of centrohelid heliozoans. For example, phylogenetic placement of the representatives of genera Pseudoraphidiophrys, Parasphaerastrum, Pseudoraphidocystis is unknown due to the absence of sequences of their ribosomal genes. Most of the SSU rRNA sequences of centrohelids from GenBank are represented by environmental lineages without any morphological data. Future molecular and morphological studies (in- 
cluding investigations of clonal cultures) will complement available information on centrohelid phylogeny and biogeography and help in understanding the distribution of morphospecies and phylotypes in fresh and marine waters.

\section{Conclusion}

The morphological data presented here expand our views on the intraspecific variability of centrohelid heliozoans and broaden our knowledge of centrohelid diversity and geographic distribution. All of the observed species are new to South Korea. The combination of unique morphological features and molecular phylogenetic data allows us to attribute the studied strain HMzp-2 to a new species Pterocystis jongsooparkii sp. nov.

\section{Acknowledgements}

This work was supported by the Russian Science Foundation grant No. 18-14-00239. We are grateful to Prof. Jong Soo Park and Mr. Soo Hwan Jhin for their help with samples collection and organising the field survey. The English language check and manuscript proofreading was carried out by Effective Language Tutoring Services (http://effect19. tmweb.ru/).

\section{References}

Adl S.M., Bass D., Lane C.E., Lukeš J., Schoch C.L. et al. 2019. Revisions to the classification, nomenclature, and diversity of eukaryotes. J. Eukaryot. Microbiol. 66 (1), 4-119.

Archer W. 1867. Raphidiophrys viridis. Q. J. Microsc. Sci. 7, 178-179.

Archer W. 1869. On some freshwater Rhizopoda, new or little-known. Q. J. Microsc. Sci. 9, 250-271.

Arndt H. 1993. A critical review of the importance of Rhizopods (naked and testate amoebae) and Actinopods (Heliozoa) in lake plankton. Mar. Microb. Food Webs. 7 (1), 3-29.

Burki F., Kaplan M., Tikhonenkov D.V., Zlatogursky V., Minh B.Q., Radaykina L.V., Smirnov A., Mylnikov A.P. and Keeling P.J. 2016. Untangling the early diversification of eukaryotes: a phylogenomic study of the evolutionary origins of Centrohelida, Haptophyta and Cryptista. Proc. Royal Soc. B. 283 (1823), 20152802.
Capella-Gutierrez S., Silla-Martinez J.M. and Gabaldon T. 2009. TrimAl: a tool for automated alignment trimming in large-scale phylogenetic analyses. Bioinformatics. 25 (15), 1972-1973.

Carter H.J. 1863. On a freshwater species of Echinocystidia, Acanthocystis turfacea, n. sp. et gen. Ann. Mag. Nat. Hist. 12 (3), 263-264.

Carter H.J. 1865. On the fresh- and salt-water Rhizopoda of England and India. J. Nat. Hist. 88, 277-292.

Cavalier-Smith T., Lewis R., Chao E.E., Oates B. and Bass D. 2009. Helkesimastix marina n. sp. (Cercozoa: Sainouroidea superfam. n.) a gliding zooflagellate of novel ultrastructure and unusual ciliary behaviour. Protist, 160, 452-479.

Cavalier-Smith T. and Chao E.E. 2012. Oxnerella micra sp. n. (Oxnerellidae fam. n.), a tiny naked centrohelid, and the diversity and evolution of heliozoan. Protist. 163, 574-601.

Cavalier-Smith T. and von der Heyden S. 2007. Molecular phylogeny, scale evolution and taxonomy of centrohelid heliozoan. Mol. Phylogen. Evol. 44 (3), 1186-1203.

Croome R. 1986. Observations of the Heliozoan genera Acanthocystis and Raphidocystis from Australia. Arch. Protistenkd. 131, 189-199.

Croome R. 1987. Observations of the genera Acanthocystis, Raphidiophrys, Clathrulina and Pompholyxophrys (Protozoa, Sarcodina) from Australian freshwaters. Arch. Protistenkd. 133, 237-243.

Croome R.L., van den Hoff J. and Burton H.R. 1987. Observations of the heliozoean genera Pinaciophora and Acanthocystis (Heiliozoea, Sarcodina, Protozoa) from Ellis Fjord, Antarctica. Polar Biol. 8, 23-28.

Drachko D., Shishkin E. and Zlatogursky V.V. 2020. Phenotypic masquerade: polymorphism in the life cycle of the centrohelid heliozoan Raphidiophrys heterophryoidea (Haptista: Centroplasthelida). Eur. J. Protistol. 73, 125686.

Dürrschmidt M. 1985. Electron microscopic observations on scales of species of the genus Acanthocystis (Centrohelidia, Heliozoa) from Chile. I. Arch. Protistenkd. 129, 55-87.

Dürrschmidt M. 1987a. An electron microscopical study of freshwater Heliozoa (genus Acanthocystis, Centrohelidia) from Chile, New Zealand, Malaysia and Sri Lanka. II. Arch. Protistenkd. 133, 21-48.

Dürrschmidt M. 1987b. An electron microscopical study on freshwater Heliozoa (genus Acanthocystis, Centrohelidia) from Chile, New Zealand, Malaysia and Sri Lanka. III. Arch. Protistenkd. 133, 49-80. 
Gaponova L. 2008. The Centrohelid heliozoans (Protista, Centrohelida) of algal mats from the water body in Ukrainian Polissya. Vestnik Zoologii. 42 (2), e-38-e41.

Gerasimova E.A., Plotnikov A.O., Khlopko Y.A. and Zlatogursky V.V. 2020. Multiple euryhaline lineages of centrohelids (Haptista: Centroplasthelida) in inland saline waters revealed with metabarcoding. J. Eukaryot. Microbiol. 67, 223231.

Gouy M., Guindon S. and Gascuel O. 2010. SeaView Version 4: A multiplatform graphical user interface for sequence alignment and phylogenetic tree building. Mol. Phyl. Evol. 27, 221-224.

Greeff R. 1869. Über Radiolarien und Radiolarienartige Rhizopoden des süssen Wassers. Arch. Mikrosk. Anat. Enwicklmech. 5, 464-505.

Greeff R. 1873. Über Radiolarien und Radiolarienartige Rhizopoden des süssen Wassers. Sitzungsb. d. Gesellsh. zu Marb. 5, 47-64.

Katoh K., Kuma K., Toh H., Miyata T. 2005. MAFFT version 5: improvement in accuracy of multiple sequence alignment. Nucleic Acids Res. 33 (2), 511-518.

Kosolapova N.G. and Mylnikov A.P. 2015. First records of centrohelid heliozoans (Centrohelida) in Mongolia. Inland Water Biology. 8 (3), 232-235.

Kuraku S., Zmasek C.M., Nishimura O. and Katoh K. 2013. aLeaves facilitates on-demand exploration of metazoan gene family trees on MAFFT sequence alignment server with enhanced interactivity. Nucleic Acids Res. 41, W22-W28.

Leonov M.M. 2009. Heliozoan fauna of waterbodies and watercourses of the Central Russian upland forest-steppe. Inland Water Biol. 2, 6-12.

Leonov M.M. 2010. Heliozoans (Heliozoa, Sarcodina, Protista) of fresh and marine waters of the European part of Russia: species composition, morphology, and distribution. Inland Water Biol. 3 (4), 344-355.

Leonov M.M. and Mylnikov A.P. 2012. Centroheliozoa from Southern Karelia. Zool. Zhurn. 91, 515-523 (in Russian with English summary).

Leonov M.M. and Plotnikov A.O. 2009. Species composition, morphology, and distribution of centrohelid heliozoa from Central Chernozem Region and the South Urals. Zool. Zhurn. 88, 643-653 (in Russian with English summary).

Leonov M.M. 2010. New species of centrohelid heliozoa of the genus Acanthocystis (Centroheliozoa). Zool. Zhurn. 89 (5), 507-513 (in Russian with English summary).
Mikrjukov K.A. 1993a. Observations on Centroheliozoa of the Volga basin (Protozoa: Sarcondina). Zoosyst. Rossica. 2, 201-209.

Mikrjukov K.A. 1993b. On the centrohelid and rotosphaerid Heliozoa from the environs of the Võrtsjärv limnological station in Estonia. Proc. Estonian Acad. Sci. 42 (2), 154-160.

Mikrjukov K.A. 1994a. Observations of Centrohelionzoa from Moscow Marine Aquaria. Arch. Protistenkd. 144 (4), 450-455.

Mikrjukov K.A. 1994b. Marine and brackishwater centrohelids (Centroheliozoa, Sarcodina) of Kandalaksha Bay of the White Sea. Zool. Zhurn. 73 (6), 5-17 (in Russian with English summary).

Mikrjukov K.A. 1996a. Revision of the genera and species composition of lower Centroheliozoa I. Family Heterophryidae Poche. Arch. Protistenkd. 147 (1), 107-113.

Mikrjukov K.A. 1996b. Revision of genera and species composition of lower Centroheliozoa. II. Family Raphidiophryidae n. fam. Arch. Protistenkd. 147 (2), 205-212.

Mikrjukov K.A. 1997. Revision of the genera and specific composition of the family Acanthocystidae (Centroheliozoa, Sarcodina). Rus. J. Zool. 1 (2), 119-130.

Mikrjukov K.A. 1999. Interesting findings of Heliozoa (Protista) in Black Sea and Crimea: data on similarity on sea and freshwater fauna of these organisms. Zool. Zhurn. 78, 517-27 (in Russian with English summary).

Mikrjukov K.A. 2002. Centrohelid heliozoans (Centroheliozoa). KMK Sci. Press, Moscow (in Russian).

Nguyen L.T., Schmidt H.A., Haeseler A. and Minh B.Q. 2015. IQ-TREE: A fast andeffective stochastic algorithm for estimating maximum likelihood phylogenies. Mol. Biol. Evol. 32, 268274.

Nicholls K.H. 1983. Little-known and new heliozoeans: the centrohelid genus Acanthocystis, including descriptions of nine new species. Can. J. Zool. 61 (6), 1369-1386.

Nikolaev S.I., Berney C., Fahrni J.F., Bolivar J., Polet S., Mylnikov A.P., Aleshin V.V., Petrov N.V., and Pawlowski J. 2004. The twilight of Heliozoa and rise of Rhizaria, an emerging supergroup of amoeboid eukaryotes. PNAS. 101, 8066-8071.

Ostenfeld C.H. 1904. On two new marine species of Heliozoa occurring in the plankton of the Nord Sea and Scager Rak. Medd. Komm. Havunters ogelzer, Ser. Plankton. 1, 3-5. 
Penard E. 1889. Notes sur quelques Heliozoaires. Arch. Sci. Phys. Nat. 22, 524-539.

Penard E. 1890. Die Heliozoen der Umgebung von Wiesbaden. Jahrb. Nassau. Ver. Naturkd. 43, 39-66.

Plotnikov A.O. and Gerasimova E.A. 2017. Heliozoa (Centrohelea, Haptista, Hacrobia) of saline and brackish water bodies and watercourses of Russia. Inland Water Biol. 10, 121-129.

Prokina K.I., Zagumyonnyi D.G. and Philippov D.A. 2017a. Centrohelids in the mires of Northern Russia. Protistology. 11 (1), 3-19.

Prokina K.I., Mylnikov A.P. and Zelalem W. 2017b. First data on heterotrophic flagellates and heliozoans of Ethiopia. Biol. Bull. 44, 896-912.

Prokina K.I., Zagumyonnyi D.G. and Tikhonenkov D.V. 2018. Centrohelid Heliozoans (Centroplasthelida Febvre-Chevalier et Febvre, 1984) from different types of freshwater bodies in the Middle Russian forest-steppe. Acta Protozool. 57, 245-268.

Prokina K.I. and Mylnikov A.P. 2019. Centrohelid heliozoans from freshwater habitats of South Patagonia and Tierra del Fuego, Chile. Inland Water Biol. 12, 10-20.

Prokina K.I. and Philippov D.A. 2019. Centrohelid heliozoans (Haptista: Centroplasthelida) from mires in the North Caucasus, Russia. Mires and Peat. 24 (36), 1-20.

Prokina K.I., Zagumyonnyi D.G. and Mylnikov A.P. 2019. Marine Centrohelid heliozoans (Centroplasthelida Febvre-Chevalier et Febvre, 1984) from bays of Sevastopol (The Black Sea shore). Russ. J. Mar. Biol. 45 (5), 377-384.

Prokina K.I., Radaykina L.V. and Mylnikov A.P. 2020. Centrohelid Heliozoans (Centroplasthelida Febvre-Chevalier et Febvre 1984) from Vietnam. Biol. Bull. 47(7), 29-40.

Ronquist F. and Huelsenbeck J.P. 2003. MrBayes 3: Bayesian phylogenetic inference under mixed models. Bioinformatics. 19 (12), 1572-1574.

Shatilovich A.V., Mylnikov A.P. and Stoupin D.V. 2010. The fauna and morphology of heterotrophic flagellates and heliozoans from Late Pleistocene fossil rodent burrows (Kolyma Lowland). Zool. Zhurn. 89( 4), 387-397 (in Russian with Englich summary).

Shishkin Y., Drachko D., Klimov V.I. and Zlatogursky V.V. 2018. Yogsothoth knorrus gen. n., sp. n. and Y. carteri sp. n. (Yogsothothidae fam. n., Haptista, Centroplasthelida), with notes on evolution and systematics of centrochelids. Protist. 169, 682-696.
Siemensma F.J. 1991. Klasse Heliozoa Haeckel, 1866. Protozoenfauna. Vol. 2.

Siemensma F.J. and Roijackers R.M.M. 1988a. A study of new and little-known acanthocystid heliozoeans, and a proposed division of the genus Acanthocystis (Actinopoda, Heliozoea). Arch. Protistenkd. 135 (1-4), 197-212.

Siemensma F.J. and Roijackers R.M.M. 1988b. The genus Raphidiophrys (Actinopoda, Heliozoea): scale morphology and species distinctions. Arch. Protistenkd. 136 (3), 237-248.

Stensdotter-Blomberg U. 1998. Factors controlling pelagic populations of ciliates and heliozoans late summer investigations in an acidic lake before and after liming. J. Plankton Res. 20 (3), 423-442.

Tikhonenkov D.V. and Mylnikov A.P. 2011. Choanocystis antarctica sp. n., a new heliozoan (Centrohelida) species from the littoral zone of King George Island, South Shetland Islands, Antarctica. Biol. Bull. 38 (7), 663-666.

Tong S., Vørs N. and Patterson D.J. 1997. Heterotrophic flagellates, Centrohelid heliozoa and filose amoebae from marine and fresh water sites in the Antarctic. Polar Biol. 18, 91-106.

Vørs N. 1992. Heterotrophic amoebae, flagellates and heliozoa from the Tvarminne area, Gulf of Finland, in 1988 - 1990. Ophelia. 36 (1), 1-109.

Wujek D.E. and Ogundipe O.T. 2002. Heliozoa from Nigeria. Trop. Freshwat. Biol. 11 (1), 1-9.

Wujek D.E. and Saha L.C. 2006. Freshwater scaled heterotrophic flagellates and heliozoa from India including a description of a new species of Choanocystis. J. Bombay Nat. Hist. Soc. 103 (1), 71-81.

Zagumyonnyi D.G., Gusev E.S., Mylnikov A.A. and Mylnikov A.P. 2020. Novel species of centrohelid heliozoans (Centroplasthelida) for freshwaters of central and southern Vietnam. Inland Water Biol. 13 (3), 358-371.

Zlatogursky V.V. 2010. Three new freshwater species of centrohelid heliozoans: Acanthocystis crescenta sp. nov., A. kirillisp. nov., and Choanocystis minima sp. nov. Eur. J. Protistol. 46 (3), 159-163.

Zlatogursky V.V. 2012. Raphidiophrys heterophryoidea sp. nov. (Centrohelida: Raphidiophryidae), the first heliozoan species with a combination of siliceous and organic skeletal elements. Eur. J. Protistol. 48 (1), 9-16.

Zlatogursky V.V. 2014. Two new species of centrohelid heliozoans: Acanthocystis costata sp. nov. and Choanocystis symna sp. nov. Acta Protozool. 53 (4), 313-324. 
Zlatogursky V.V. 2016. There and back again: parallel evolution of cell coverings in centrohelid heliozoans. Protist. 167 (1), 51-66.

Zlatogursky V.V., Gerasimova E.A. and Plotnikov A.O. 2017. A new species of centrohelid heliozoan Acanthocystis amura n. sp. isolated from two remote locations in Russia. J. Eukaryot. Microbiol. 64(4), 434-439.

Zlatogursky V.V., Drachko D., Klimov V.I. and Shishkin Y. 2018. On the phylogenetic position of the genus Raphidocystis (Haptista: Centroplasthelida) with notes on the dimorphism in centrohelid life cycle. Eur. J. Protistol. 64, 82-90.

Zlatogursky, V. V., Gerasimova, E. A., Drachko, D., Klimov, V. I., Shishkin, Y., and Plotnikov, A. O. 2019. Pinjata ruminata gen. et sp. n. - A new member of centrohelid family Yogsothothidae (Haptista: Centroplasthelida) from the brackish river. J. Eukaryot. Microbiol. 66 (6), 862-868.

Address for correspondence: Dmitry G. Zagumyonnyi. Papanin Institute for Biology of Inland Waters of Russian Academy of Sciences, 142742 Borok, Nekouzskiy district, Yaroslavl Region, Russia; e-mail: zdmitryg@gmail.com 